\title{
IDEOLOGI KH. ABDURRAHMAN WAHID DAN BANGUNAN PENDIDIKAN MULTIKULTURAL PASCA TRAGEDI KEBANGSAAN
}

\author{
Siti Qomala Khayati \\ Sekolah Tinggi Agama Islam Nahdlatul Ulama Temanggung, Indonesia \\ E-mail: hayatiqomala@gmail.com
}

\begin{abstract}
Abstrak: Tulisan ini bisa dikatakan sebagai sebuah pengaya kajian pendidikan multikultural yang sudah lama diperbincangkan di Indonesia, melalui cara menampilkan tokoh baru (baca; Gus Dur) yang sejatinya tidak pernah menjadikan pendidikan mutikultural sebagai gagasan pemikirannya. Keberadaan Gus Dur lebih sebagai ideolog pemikiran multikultural. Oleh karena itulah maka, tulisan ini lebih terbentuk pada proses rekonstruktif pemikiran Gus Dur secara general dalam hal keislaman, kebudayaan, dan diskursus ideologis di Indonesia, yang dikontekskan pada dunia pendidikan. Selain itu, secara implementatif, tulisan ini juga akan didesain melalui pendekatan teori sismtem di dalam dunia pendidikan. Agar supaya pemikiranpemikiran yang tidak spesifik itu menjadi lebih praktis dan bisa dijadikan strategi para guru dalam menjalankan pembelajarannya di lembaga pendidikan. Terakhir, berdasarkan penelitian ini, pelajaran terpenting dari pemikiran cultural dan sikap ideologis Gus Dur, untuk membangun pendidikan berbasis multikulturalisme di Indonesia, berada pada kuatnya Gus Dur berprinsip bahwa Bhinneka Tunggal ika merupakan identitas masyarakat yang tidak bisa dirubah oleh kekuatan politik manapun, Pancasila sebagai landasan ideologis yang wajib dipahami dan dihayati semua kalangan masyarakat di Indonesia, serta berpegang teguh pada aturan main berbangsa dan bernegara di Indonesia apakah itu melalui nilai-nilai kebudayaan dan keagamaan integrative yang hidup Negara Kesatuan Republik Indonesia serta kandungan subtansial Undang-Undang Dasar Tahun 1945, yang merangkul semua kalangan tanpa membedakan SARA.
\end{abstract}

Kata Kunci: Gus Dur, Ideologi Bangsa, dan Pendidikan Multikultural

\section{Pendahuluan}

Diskursus pendidikan multikultural, sejatinya, memang tidak pernah hadir pada ruang kosong. Hampir bisa dipastikan, gagasan ini hadir kala sebuah negara mengalami ancaman konflik horizontal dan disintegritas sosial karena hadirnya krisis kepercayaan kelompok yang satu terhadap yang lainnya. Di Amerika misalnya, pendidikan multikultural dihadirkan untuk meminimalisir living conflict antara kelompok kulit putih dan hitam. ${ }^{1}$ Di Inggris, model pendidikan dijadikan tawaran

\footnotetext{
${ }^{1}$ James A. Banks, Multiethnic education: Theory and practice (London: Oxford University Press, 1994), 23 
untuk mendesiminasikan nilai masyarakat global dan proteksionisme negara demokratis kepada semua pendatang (immigrant/diasporas society) di negara tersebut. ${ }^{2}$ Di Indonesia sendiri, sebagaimana catatan Azyumardi Azra ${ }^{3}$ dan HAR Tilaar, ${ }^{4}$ gagasan ini hadir disebabkan adanya tragedy kebangsaan sebelum reformasi, otonomisasi kewenangan, dan demokratisasi-subtantif (menghindari istilah demokrasi liberal), dijalankan di Indonesia. Sejarah pun mencatat bahwa, kondisi Indonesia kala itu menghadap krisis multi dimensi; mulai dari kuatnya distrust terhadap pemerintah, intoleransi terhadap agama lain, konflik masyarakat akibat persoalan ekonomi dan sosial, serta riak konflik berbasis pada perbedaan budaya di wilayah-wilayah tertentu. ${ }^{5}$

Meskipun sudah terwacanakan dan menjadi mainstream-discourse di kalangan akademisi, konsep pendidikan multikultural tidak banyak terlihat dalam bentuk implementatif. Ditambah lagi, keterbukaan informasi dan perkembangan isu-isu perpecahaan di masyarakat yang tambah beragam, menghilangkan kesuksesan konsep ini. Oleh karena itulah, tidak diskursus ini masih saja hangat untuk diperbincangkan hanya sekedar untuk me-reaktualisasi dan merestrategi pengembangan yang sudah banyak dimunculkan tersebut. Misalnya, pendidikan multikultural dikaitkan dengan para penggasnya di Indonesia. ${ }^{6}$ Pendidikan multikultural dikaitkan dengan nilai-nilai kebangsaan dan nilai-nilai demokrasi hari ini. ${ }^{7}$ Pendidikan multikultural vis a vis

2 G.C. Baker, Planning and Organizing for Multicultural Instruction. (2), (California: Addison-Elsey Publishing Company, 1994), 89

3 Azra dalam beberapa tulisan tentang pendidikan multikuktural, menyatakan bahwa keberadaan konsep untuk menyangkal adanya asumsi pengarusutamaan pendidikan agama pada UU Sisdiknas Tahun 2003 mengandung potensi untuk terjadinya kembali konflik keagamaan di Indonesia. Pendidikan multikultural akan didesain menyesuaiakan pada kontek keagamaan dan kebudayaan Indonesia yang beragam. Maka dari itu memang, harus ada perumusan yang integrative di dalamnya antara tradisi dan keyakinan keagamaan dengan kondisi budaya yang ada. Gagasan Azra ini juga dimunculkan oleh banyak pemikir Islam pada waktu itu. Supaya ketegangan pembahasan mainstreaming agama tidak dipersoalkan lagi. Lihat Azyumardi Azra, "Pendidikan Agama: Membangun Multikulturalisme Indonesia" Kata Pengantar dalam Zakiyuddin Baidhawy, Pendidikan Agama Berwawasan Multikultural (Surabaya; Impulse, 2004) vii

4 H.A.R Tilaar, Kekuasaan dan Pendidikan Manajemen Pendidikan Nasional dalam Pusaran Kekuasaan (Bandung; Alpabeta, 2003), 209

${ }^{5}$ Setidaknya dari ingatan yang masih terekam di benak penulis, kasus-kasus criminal dan intoleran sebelum 1998 ialah tragedy pembakaran rumah ibadah agama, penjarahan toko, terorisme berbasis agama, dan perlakuan tidak adil melalui peraturan yang dilakukan oleh daerah terhadap kelompok agama tertentu.

${ }^{6}$ Muhammad Isnaini, Konsep Pendidikan Multikultural Dalam Merespon Tantangan Globalisasi (Bandung: Alpabeta, 2010), 43.

7 Zakiyuddin Baidhawy, The Problem of Multikulturalisme: Radicalism Mainstreaming Trought Religious Preaching in Surakarta. Journal of Indonesia Islam, vol 04, Nomor 02, (Surabaya: IAIN Sunan Ampel, 2010), 275 
ideologisasi nilai-nilai keagamaan, termasuk di dalamnya keislaman. ${ }^{8}$ Pendidikan multikultural dalam bentuk kelembagaan sekolah. ${ }^{9}$ Dan kajian-kajian lainnya.

Berdasarkan ragam kajian terdahulu tersebut, maka penulispun ingin turut andil melengkapi kajian, melalui cara membaca pemikiran idolog kemanusiaan bernama Abdurrahman Wahid (Gus Dur). Kendati, Gus Dur sendiri tidak memiliki karya yang spesifik terkait pendidikan multikultural, berdasarkan pada karya akademik yang dihasilkan. Para penulis pemikiran pendidikan multikultural Gus Dur ${ }^{10}$ memiliki kecenderungan hanya sekedar mengambil aspek pemikiran keislaman, kindonesiaan, pluralitas kebudayaan, dan lainnya, kemudian dikontekskan pada fondasi teoritik pendidikan multikultural. Oleh karenanya, agar sedikit berbeda dengan kajian sebelumnya, penulis akan menfokuskan pada ciri pemikiran gus dur; basis pemikiran kultural dan ideologis, lalu dianalisa melalui pendekatan teori sistem pendidikan (input-process-output interrelation). Penulis juga, dalam hal mensistematikakan pemikiran Gus Dur dan Pendidikan Multikultural, akan menjauhi pengulangan-pengulangan; semisal, historiografi kehidupan Gus Dur, konsepsi akademik yang tidak berhubungan dengan kajian kebudayaan dan ideology, serta kehidupan politik Gus Dur. Posisi Gus Dur akan ditempatkan sebagai pemikir yang murni konsisten menjalani keyakinannya.

Maka dari itu, pada tulisan ini, penulis akan lansung menyajikan konsepsi pemikiran Gus Dur terkait ideology kebangsaan dan tantangan pluralitas masyarakat Indonesia, sikap ideologis Gus Dur dan rangkaian teoritik pendidikan multikultural, hingga analisis sistemik dan implikatif pendidikan multikultural dalam lingkup lembaga pendidikan. Di akhir gagasan, penulis akan memberikan nama hingga implikasi praktis sistemik bagaimana pemikiran Gus Dur bisa menjadi fondasi pendidikan multikultural, yang tidak sekedar terwacanakan di kelas, desain kurikulum, dan proses pembelajaran lainnya, melainkan lebih pada sistem kelembagaan secara holistik.

\footnotetext{
${ }^{8}$ H.A.R Tilaar, Pendidikan, Kebudayaan, dan Masyarakat Madani Indonesia, (Jakarta: Rineka Cipta, 2004), 59

${ }^{9}$ Choirul Mahfud, Pendidikan Multikultural, (Yogyakarta: Pustaka Pelajar, 2006), 103

${ }^{10}$ Misbahul Munir, Tesis, Pemikiran KH. Abdurrahman Wabid Tentang Islam Berwawasan Multikultural Dan Implikasinya Terbadap Pendidikan Islam, (Surabaya: PAI Pasca Sarjana, UIN Sunan Ampel, 2014) dan Musthofa dengan judul yang sama Pendidikan Multikultural dalam perspektif Gus Dur di FTK UIN Malang, Tahun 2015. 


\section{Konsepsi Pemikiran Ideologis Gus Dur dan Tantangan Masyarakat Plural di Indonesia}

Kegelisahan Gus Dur terkait kontestasi paradigma kemajemukan (baca; nasional atau Islam di Indonesia) seraya membuatnya berfikir atau melakukan rekontekstualisasi terhadap beberapa kerangka epistemik yang Gus Dur bangun sendiri secara dialektis. Banyak pemikir Islam yang menganggap Gus Dur melampui komponen-komponen standard yang dibentuk untuk melegitimasi sebuah kebenaran pemikiran. Gus Dur, bisa dirupakan sebagai pemikir Islam tradisional, sebab kajian yang disajikannya tidak pernah dilepaskan dari identitas pribadinya sebagai seorang pemikir dari pesantren. Gus Dur, bisa pula dipresentasikan sebagai kelompok modernis, karena pemikirannya berasal dari terminology modern. Gus Dur juga bisa dipresentasikan sebagai pengintegrasi dua sudut pandang yang berbeda tersebut, karena di dalam karyanya, sering ada paradigma dialogis antara kekuatan peradaban Timur dan Barat.

Betapapun, Gus Dur adalah sosok yang sarat kaya pengalaman dan pengetahuan; baik itu Barat dalam pengertian ilmu pengetahuan umum, Timur dalam bingkai pengetahuan Islam. Gus Dur sendiri, mengatakan bahwa sebagai sebuah sudut pandang Barat dalam menciptakan metodologi tidak perlu disembah untuk mengukur kebenaran yang ada pada ajaran Islam. Demikian sebaliknya, instrumentmetodologis yang dimiliki oleh Islam tidak elok juga dijadikan basis yang statis, sehingga metode lain tidak bisa digunakan untuk mencari kebenaran dalam menentukan nilai-nilai keberagamaan. ${ }^{11}$ Jadi, bagi Gus Dur cara berfikir yang baik adalah inklusifitas diri terhadap semua metodologi, kemudian mereduksinya menggunakan instrument kepantasan, kelayakan, dan pertimbangan-pertimbangan kontekstual (axiology). Melalui berfikir seperti itu, maka sebuah produk pemikiran tidak akan menghadirkan gejolah baru di dalam kehidupan masyarakat secara luas.

Gus Dur, dikala dia menanggapi sebuah kasus atau fenomena di dalam masyarakat, acapkali menggunakan model seperti ini. Misalnya dalam tulisannya

11 Abdurrahman Wahid, Prisma Pemikiran Gus Dur (Yogyakarta: LKiS, 2010), 23 
bertajuk "Islam; Pokok dan Rincian" Gus Dur memaparkan pandangan-pandangan Islam berhubungan tentang ajaran Islam, kemudian membandingkannya melalui pandangan agama lain (baca; Kristen-Katolik), lalu diakhiri melalui paradigma Islam khas Indonesia dimana Gus Dur tumbuh dan berkembang. ${ }^{12}$ Gus Dur menganggap konteks ke-Indonesian memiliki perbedaan yang signifikan dengan negara-negara yang sudah disebutkan sebelumnya. Walaupun sama-sama ada kekuatan dan kekuasaan agama di dalamnya. Contoh lain bagaimana Gus Dur sering juga mengangkat pengalaman pribadinya dididik oleh para pendahulunya sebagai sebuah persepktif. Gus Dur, dalam beberapa tulisannya, 'selalu mengutip pandangan para kiai, orang tua, dan guru-guru yang mempengaruhinya. ${ }^{13}$

Jadi, Gus Dur selalu menyandingkan apa yang diketahui dengan pengelaman pribadi, konteks sosial, dan pola konsep pemikiran yang terbaik, sehingga bisa diterima secara seksama oleh semua orang. Selain itu, Gus Dur juga tidak melihat apa yang sudah diyakininya sebagai satu kebenaran yang wajib diikuti. Gus Dur, dikala merumuskan gagasan, sangat terbuka terhadap kritik dan perspektif yang berbeda dengannya. Maka dari itu, Gus Dur selalu dianggap sebagai seorang sosok yang konsisten di dalam inkonsistensi-progresif. Artinya, jikasaja, ada pandangan yang lebih proporsional dan mengena terhadap masyarakat, Gus Dur tidak segan-segan untuk menerima hal tersebut sebagai bentuk pemikiran yang baru dan harus diikuti oleh semua orang.

Pada intinya, proses paradigmatik - khususnya bagi mereka yang ingin membaca Gus Dur - harus tertemakan pada aspek inklusifitas paradigma, pergeseran, kontekstulitas, dan penerimaan terhadap perbedaan-perbedaan gagasan untuk menghasilkan konsepsi yang paling baik. Setidaknya, ini pulalah yang kemudian menjadikan Gus Dur dikategorikan sebagai Bapak Pluralisme. Sosok yang sangat menghargai perbedaan-perbedaan yang terjadi dan menjadi wujud otentik masyarakat Indonesia secara luas.

12 Wahid, Islamku, 139

13 Ibid., 142 
1. Sikap Ideologis-Multikultural Gus Dur

Sebelum membahas bagian ini, penulis ingin menyebutkan dulu beberapa hal penting yang menjadi konstruksi bahasan topik ini. Pertama, bentuk sikap (baca; perilaku, respon, dan tindakan) yang ditunjukkan oleh Gus Dur sebagai keyakinan sosialogis (ideology) terkait problematika multikulturalisme di Indonesia. Kedua, rasionalisasi Gus Dur terhadap sikap tersebut, agar kemudian, menjadi bagian konstruktif dalam perilaku kolektif di Indonesia yang majmuk. Ketiga, bentuk kesadaran Gus Dur bahwa pilihan idologisnya merupakan bentuk formatif yang bisa ditiru untuk menciptakan peradaban baru yang ada di Indonesia. Dalam konteks ini, penulis akan membingkainya melalui berbagai informasi yang terangkum dalam karya tulis (baca; opini), liputan berita, dan ulasan dari pelbagai suntingan karya Gus Dur. Melaui pemaparan ini, setidaknya, akan terlihat bagaimana sebenarnya sikap multikultural itu harus ditunjukan. Bagaimana sikap ideology-multikultural ini bisa termanifestasi inheren dalam kehidupan sehari-hari di masyarakat Indonesia.

Untuk menunjukkan sikap ideologis, berdasarkan pada data media, penulis akan mengkonstruksinya mulai dari upaya Gus Dur, Fahmi Syaifudin Zuhri, dan KH. Ahmad Sidiq untuk menjadikan NU sebagai organisasi Islam yang menerima keberadaan ideologi Pancasila sebagai asas tunggal di dalam berbangsa dan bernegara. ${ }^{14}$ Alasan Gus Dur cukup menarik dalam hal ini; secara teologis, tegas Gus Dur menganggap kepemimpinan dan ideologisasi sikap masyarakat merupakan hal yang diwajibkan oleh agama Islam. Gus Dur mengutip la Islama illa bi al jama'ah, la jama'ata illa bil imarah, wa la imarata illa bi al tha'ah. ${ }^{15}$ Secara sosiologis-historis, Indonesia sudah menyematkan dirinya sebagai negara yang diasaskan pada Pancasila, dengan identitas Bhinneka Tunggal Ika, NKRI sebagai sistem kesatuan (baca; republic) dan UUD 45 sebagai fondasi aturan/hukum yang mengatur sistem kemasyarakatan yang ada di Indonesia. ${ }^{16}$

\footnotetext{
${ }^{14}$ Lihat "Gus Dur dan Gagasan Pancasila sebagai Ideologi Negara” berita online, diakses melalui nuonline.or.id pada tanggal 23 Maret 2017

15 Wahid, Islamku, 203

16 Lihat "Gus Dur tegaskan Pancasila Sudah Final" berita online, diakses pada Surabaya.tribunnews.com pada tanggal 23 maret 2017
} 
Sikap lainnya adalah terlihat bagaimana Gus Dur melakukan pembelaan terhadap kelompok keberagamaan minoritas, pembelaan terhadap masyarakat etnik yang terancam keberadaannya di Indonesia, ${ }^{17}$ hingga pada konflik-konflik individual (HAM), seperti Inul Daratistas, Ulil Abshar Abdalla, dan Basuki Tjahya Purnama. Jika membaca alasan Gus Dur melakukan pembelaan tersebut, sangat jelas, bahwa Gus Dur melandaskan tindakannya karena adanya aturan ideologis yang mewajibkannya melakukan tindakan tersebu. Di dalam interview-nya dalam acara Kick Andy misalnya, juga sangat terlihat bagaimana Gus Dur mengatakan bahwa, semua yang dilakukannya sebab UUD 45 mewajibkan itu, Pancasila dan Bhinneka Tunggal Ika adalah identitas yang sudah tumbuh di Bumi Nusantara 7 Abad lamanya tanpa nama, hingga cerita bagaimana Gus Dur mengupayakan rekonsiliasi nasional pasca era reformasi.

Adapun pandangan sikap Gus Dur yang termanifestasi dalam karyakaryanya misalnya, Gus Dur melakukan kontestasi ideologis antara nasionalisme, islamisme, dan integrasi keduanya. Dia menulisnya dengan judul "Adakah Sistem Islami”. Setidaknya gagasan Gus Dur terkait kontestasi tersebut adalah sebagaimana berikut:

"bagi mereka yang terbiasa dengan formalisasi, tentu digunakan penterjemahan kata al silmi itu dengan kata Islami, dan denggan demikian mereka terikat kepada sebuah sistem yang dianggap mewakili keseluruhan perwujudan ajaran Islam dalam kehidupan sebagai sesuatu yang biasa dan lumrah. Hal ini membawakan implikasi adanya keperluan akan sebuah sistem yang dapat mewakili keseluruhan aspirasi kaum muslimin. Karena dapat dimengerti mengapa ada yang menganggap penting perwujudan "partai politik islam" dalam kehidupan berpolitik.....",

Dari paparan diatas, Gus Dur ingin menanamkan sikap pluralistik dalam keberagamaan dan kenegaraan. Karena, diyakini oleh Gus dur bahwa, dalam kerangka kehidupan bernegara sebuah bangsa, sistem Islami secara otomatis membuat warga negara non muslim berada dibawah kedudukan warga negara yang menganut agama Islam. Di dalam al Qur'an juga disebutkan, lanjut Gus

\footnotetext{
${ }^{17}$ Lihat "Gus Dur, Rhoma, dan goyang ngebor" berita online, diakses melalui merdeka.com pada tanggal 23 maret 2017

18 Abdurrhman Wahid, “adakah Sistem Islami” dalam Abdurrahman Wahid, Islamku, Islam Anda, Islam Kita, (Jakarta: The Wahid Institute, 2006), 4 
Dur, ada sebuah ayat yang menyatakan adanya lima syarat untuk dianggap sebagai muslim yang baik, pertama, menerima prinsip-prinsip keimanan, kedua, menjalankan ajaran (rukun) Islam secara utuh, ketiga, menolong mereka yang memerlukan pertolongan (sanak saudara, anak yatim, fakir miskin dan sebagainya). keempat, menegakkan profesionalisme, dan kelima, bersikipa sabar ketika menghadapi cobaan. ${ }^{19}$ Jika kaum muslim dapat meneladani dan melakukan kelima syarat ini, dengan sendirinya tidak diperlukan kembali kembali kerangka sistem Islami menurut ajaran Islam. Dengan demikian, mewujudkan sistem Islami tidak termasuk syarat bagi seseorang untuk dianggap muslim yang taat.

Bentuk Islam yang universal telah dinyatakan dalam rangkaian ajaran Islam sendiri seperti fiqh, taubid, akblak, dan sikap hidup Islam yang menampilkan kepedulian pada unsur kemanusiaan (al-insaniyyab). ${ }^{20}$ Gus Dur lebih lanjut menguraikan:

"sementara itu, universalisme yang tercermin dalam ajaran-ajaran yang memiliki kepeduulian kepada unsur-unsur utama kemanusian itu diimbangi pula oleh kearifan yang muncul keterbukaan peradaban Islam sendiri. Keterbukaan yang membuat kaum muslim selama sekian abad menyerap segala macam manifestasi kultural dan wawasan keilmuan yang datang dari pihak peradaban-peradaban lain, baik yang masih ada waktu itu maupun yang sudah mengalami penyusutan luar biasa (seperti peradaban Persia)". 21

Sementara di bidang nasionalisme, Gus Dur mendorong negara melakukan reideologisasi dalam menunmbuhkan semangat nasionalisme dalam masyarakat Indonesia sebagaimana dikemukakan di dalam tulisannya yang berjudul "Reideologisasi dan Retradisionalisasi dalam Politik":

"proses reideologisasi itu mengambill dua pola perkembangan utama. Di satu pihak, langkanya ikatan ideologis dan kuatnya kaitan dengan rekayasa tekhnokratik membawa kepada munculnya kecenderungan menampilkan semacam ideologi alternatif yang diambilkan dari berbagai sumber: nasionalisme masa lampau, agama atau ikatan komunalistik (seperti ditampilkan oleh tuntutan kaum Sikh militan akan negara sendiri di India). Rasa kebangsaan yang baru itu walaupun tidak sekuat getaran

19 Abdurrahman Wahid, Tuhan Tidak Perlu Dibela, (Yogyakarta: LkiS, 1999), 23

20 Abdurrahman Wahid, Universialisme Islam dan Kosmopolitanisme Peradaban Islam, dalam Abdurrahman Wahid, Islam Kosmopolitan: Nilai-nilai Indonesia dan Transformasi Kebudayaan, (Jakarta: The Wahid Institute, 2007), 3

21 Wahid, Universialisme Islam, 4 
nasionalisme di masa kejayaannya, cukup menggerakkan kekuatankekuatannya sendiri dalam kehidupan masyarakat, seperti komunalisme orang Melayu di Malaysia. Dalam munculnya reideologisasi itu, agama merupakan sumber utama, seperti dapat dilihat pada berbagai gerakan fundamentalistik dan militan dalam Islam, dan pada teologi pembebasan di sejumlah aktivis Katolik di Amerika Latin. Untuk melawannya, sistem kekuasaan yang harus menghadapi munculnya ideologi alternatif itu lalu membuat refleksinya sendiri atas ideologi formal yang telah diterima semula, dan dengan cara demikian menegaskan kembali arti ideologi yang sudah mapan. Penemuan kembali ideologi yang sudah mapan, tetapi hampir dilupakan, merupakan manifestasi utama dari sejumlah negara berkembang, termasuk dengan munculnya kembali minat kepada dimensi-dimensi dan berbagai aspek Pancasila di negeri kita". ${ }^{22}$

Gus Dur menunjukkan pemantapan pola-pola untuk memperlakukan ideologi sebagai keutuhan pandangan dan cita-cita, yang menghimpun semua kekayaan hidup bangsa dalam sebuah kekuatan dahsyat dalam mempertahankan negara dan mencapai tujuan yang diinginkan bagi kesejahteraan warga negara Indonesia. Oleh karena itu, sambung Gus Dur, ideologi negara mendapat kedudukan luar biasa kuatnya, dan biasannya dimantapkan dengan menggusur paham-paham lain dari posisi ideologi masing-masing. Paham pemikiran, agama, dan rasa kebangsaan diperkenankan untuk berkembang, akan tetapi harus berada di luar kerangka ideologi formal negara.

Dari data di atas, dengan tegas Gus Dur menolak deskriminasi, kriminalisasi, dan kanalisasi ideology yang hanya bercorak pada satu paham (baca; Islam). Bagi Gus Dur kemajemukan yang sudah dilukiskan melalui Pancasila dan Bhinneka Tunggal Ika sudah tidak perlu dipertentangkan. Karena, dalam Islam sendiri, sudut pandang kepentingan social politik, dan demi kemaslahatan bersama, lebih menguntungkan jika Indonesia masih dikemas melalui ideology tersebut. Terlepas dari kerangka di atas, penulis pun menganggap perlu memberikan catatan, kalau Gus Dur adalah sosok yang sangat konsisten dalam aspek ideology ini. Gus Dur, sekalipun dalam kondisi yang tidak menguntungkan, tidak pernah merisaukan efek negatif apa yang akan dia

22 Abdurrhman Wahid, "Reideologisasi dan Retradisionalisasi dalam Politik" dalam Abdurrahman Wahid, Prisma Pemikiran Gus Dur (Yogyakarta: LKiS, 2010), 26 
dapatkan. Gus Dur terus menerus hadir sebagai sosok yang peduli, menerima, dan merangkul perbedaan melalui caranya sendiri.

Kendati penulis tidak mendapatkan cerita resminya, semua orang Indonesia sudah sangat tahu bagaimana Gus Dur selalu hadir di setiap perayaan agama lain. Di kalangan Budha dan Hindu bahkan, Gus Dur dianggap sebagai representasi dewa mereka. Di Kalangan Kristen Gus Dur sempat dibaptis sebagai golongan mereka. Apalagi di Konghucu, Gus Dur adalah bapak mereka. Sebab, Gus Dur adalah presiden yang mampu membuat pengakuan terhadap eksistensi mereka. Dengan fakta dan data ini, tak satupun dapat menyangkal bahwa keberadaan Gus Dur sebagai sosok multikultural; orang yang mampu mengawinkan sikap perbedaan sebagai aspek azali dan takdir ilahi.

2. Konsepsi Keragaman Budaya dan Islam dalam Wujud Sikap Gus Dur

Jika konsistensi sikap ideologis Gus Dur terlihat dari fakta-fakta historis, fenomenologis, dan berbasis pada data-data yang dicatat oleh orang lain, tercatat hingga menjadikan Gus Dur dianggap sebagai orang yang sangat berjasa dalam kontestasi pemantapan kontestasi ideology Pancasila, sebagai asas tunggal. Pada bagian ini, penulis ingin menggambarkan bagaimana Gus Dur memikirkan aspek-aspek cultural yang dimiliki Indonesia. Hal ini berbeda dengan sikap idelogis yang alat ukurnya sudah ada, sikap cultural lebih dinamis. Sikap cultural berarti respon Gus Dur menanggapi perubahan-perubahan antropologisme (dialectical-tention) yang terjadi akibat interaksionalisme masyarakat. Oleh sebab terwujud dalam dinamika yang luwes. Maka bisa jadi, sikap dan penilaian Gus Dur terhadap nilai kebudayaan Indonesia hari berbeda dengan yang sebelumnya.

Dalam konteks penyadian data ini, penulis akan memulainya dari, bagaimana Gus Dur menjelaskan bahwa sikap kebudayaan asli Indonesia adalah kebersamaan, gotong royong, toleran, dan mau menghormati perbedaan. Hal ini tertuang dalam tulisan Gus yang berjudul "Sistem Budaya Daerah dan Modernisasi", sebagaimana berikut:

“jelaslah dengan demikian, bahwa bermacam cara dapat digunakan untuk mengenal berbagai reaksi terhadap proses modernisasi. Ada reaksi yang menggunakan warisan sistem budaya daerah, tapi ada pula yang merumuskan reaksi mereka dalam bentuk tradisi yang tidak tersistemkan. 
Ada pula reaksi yang bersifat temporer, tapi ada pula yang bersifat permanen. Ada yang berpola umum, tapi ada pula yang menggunakan cara-cara khusus dalam memberikan reaksi." ${ }^{23}$

Selain itu, salah satu corak kebudayaan yang sangat monumental adalah bagaimana Gus Dur 'memenangkan' budaya Indonesia terhadap ajaran-ajaran normative di dalam Islam. Kata memenangkan bukan berarti menanggalkan, melainkan Gus Dur ingin melakukan reaktualisasi terhadap cara berfikir umat Islam, yang secara global, dianggapnya bermasalah karena tidak menghargai kearifan lokal. Gagasan "Pribumisasi Islam" dipaparkan gus Dur dalam dua tulisannya yang berjudul "salahkan jika dipribumikan?" di kolom majalah Tempo pada 16 Juli 1983, dan kedua, "pribumisasi Islam”, antologi tulisan di dalam Muntaha Azhari dan Abdul Mun'in Saleh. Gagasan Pribumisasi Islam dimaksudkan Gus Dur sebagai jawaban atas problem yang dihadapi umat Islam sepanjang sejarahnya, yakni bagaimana mempertemukan budaya dan norma, sebagaimana persoalan dalam ushul fiqh. ${ }^{24}$

Berkaitan dengan ide pribumisasi Islam, Gus Dur berargumen bahwa agama Islam dan budaya mempuyai independensi masing-masing, akan tetapi keduanya mempunyai wilayah yang tumpang tindih. Agama Islam bersumberkan wahyu dan memiliki normanya sendiri. Karena bersifat normatif, maka ia cenderung permanen. Sedangkan budaya merupakan buatan manusia, karena ia berkembang sesuai dengan perkembangan zaman dan cenderung untuk selalu berubah. Perbedaan ini tidak menghalangi kemungkinan manifestasi kehidupan beragama dalam bentuk budaya. Di sinila adanya akomodasi atau rekonsiliasi. Proses itu dilakukan secara alami, bukan terpaksa dan itulah proses terjadinya pribumisasi Islam. $^{25}$

Proses pertumbuhan Islam sejak nabi Muhammad, sahabat, para ulama’ tidak serta merta menolak semua tradisi pra Islam (dalam hal ini budaya

23 Abdurrahman Wahid, Sistem Budaya Daerah Kita dan Modernisasi, dalam Abdurrahman Wahid, Islamku, Islam Anda Islam Kita, Cet. II(Jakarta: The Wahid Institute, 2006), 259

${ }^{24}$ Tim INCReS, Beyond The Symbols; Jejak Antropologis Pemikiran dan Gerakan Gus Dur, (Bandung: PT Remaja Rosdakarya, 2000), 43

${ }^{25}$ Abdurahman Wahid, Islam Indonesia Menatap Masa Depan, Kata Pengantar M. Dawam Raharjo (Jakarta: P3M, 1989), 332 
masyarakat arab pra Islam). Tidak seluruh sistem ditolak Islam, tradisi dan adat istiadat setempat yang tidak bertentangan secara diametral dengan Islam dapat diinternalisasi menjadi ciri khas dari fenomena Islam di tempat tertentu. ${ }^{26}$ Demikian juga proses pertumbuhan Islam di Indonesia tidak lepas dari budaya dan tradisi masyarakat.

Pribumisasi Islam dalam segi kehidupan bangsa merupakan suatu ide yang perlu dicermati. Selanjutnya, Gus Dur mengatakan bahwa pribumisasi bukan merupakan suatu upaya menghindarkan timbulnya perlawanan dari kekuatan budaya setempat, akan tetapi justru agar budaya itu tidak hilang. Inti dari pribumisasi Islam adalah kebutuhan untuk menghindari polarisasi antara agama dan budaya, sebab polarisasi demikian memang tidak terhindarkan. ${ }^{27}$ Gagasan Gus Dur ini tampaknya ingin memperlihatkan Islam sebagai sebuah agama yang apresiatif terhadap konteks-konteks lokal dengan tetap menjaga pada realitas pluralisme kebudayaan yang ada (multikulturalisme). Dengan tegas beliau menolaj satu Islam dalam ekspresi kebudayaan misalnya semua simbol atau identitas harus menggunakan eksresi kebudayaan arab. Penyeragaman yang terjadi bukan hanya mematikan kreativitas kebudayaan umat tetapi juga membuat Islam teralinenasi dari arus utama kebudayaan nasional. Bahaya dari proses arabisasi adalah tercerabutnya masyarakat Islam di Indonesia dari akar budaya sendiri. $^{28}$

Gus Dur juga menolak adanya pencampuradukan kebudayaan baik oleh kalangan agama maupun kalangan birokrasi karena kebudayaan sangat luas cakupannya yaitu kehidupan sosial manusia (buman social life) itu sendiri. Birokratisasi kebudayaan $^{29}$ yang dilakukan akan menimbulkan kemandekan kreatifitas suatu bangsa. Kebudayaan sebuah bangsa pada hakekatnya adalah kenyataan pluralistik, pola kehidupan yang diseragamkan atau dengan kata lain sentralisasi adalah sesuatu yang sebenarnya tidak berbudaya. Pertanyaan saat ini adalah mampukan Islam tetap eksis dalam zaman yang serba modern ataukah

${ }^{26}$ Masdar, Membaca, 141

27 Abdurahman Wahid, Pergulatan Negara, Agama dan Kebudayaan (Depok: Desantara, 2001), 117

28 Masdar, Membaca, 140

${ }^{29}$ Wahid, Pergulatan, 5-9 
Islam tenggelam dalam mimpi atas kejayaan para pemikir terdahulu? sebagai pemeluk agama Islam yang baik dalam lingkup wawasan kebangsaan, Gus Dur menyarankan agar; pertama, selalu mengutamakan pencarian cara-cara yang mampu menjawab tantangan zaman dan lokalitas kehidupan tanpa meninggalkan inti ajaran agama. Kedua, Selalu ada upaya untuk melakukan reaktualisasi ajaran agama dalam situasi kehidupan yang konkrit, tidak hanya dicukupkan dengan visualisasi yang abstrak belaka. Dalam bahasa lain, agama berfungsi sebagai wahana pengayom tradisi bangsa, sedangkan pada saat yang sama agama menjadikan kehidupan berbangsa sebagai wahana pematangan dirinya. ${ }^{30}$

Bentuk Islam yang universal telah diyantakan dalam rangkaian ajaran Islam sendiri, seperti fiqh, tauhid, ahlaq, dan sikap hidup Islam yang menampilkan kepedulian pada unsur kemanusiaan (al insaniyyah). ${ }^{31}$ Islam mengemban misi memuliakan dan mengangat harkat dan martabat manusia, menegakkan kebenaran, keadilan, kemanusia, demokrasi, tolong menolong, saling menghormati dan lain sebagainya. ${ }^{32}$ Sebagaimana yang diungkapkan oleh Barton bahwa Gus Dur merupakan tokoh yang cinta terhadap budaya Islam Tradisional dan khazanah pemikiran Islam yang dihasilkan para ulama' terdahulu. namun, kecintaan ini bukan berarti keterlibatan dan penerimaan segala aspek budaya tradisional karena Gus Dur sangat kritis terhadap budaya tradisional. ${ }^{33}$ Pribumisasi Islam merupakan upaya dakwah dan menasionalisasikan perjuangan Islam, dengan harapan tak ada lagi kesenjangan antara kepentingan nasional dengan kepentingan Islam. Islam sebagai agama yang diakui di Indonesia selain agama-agama lain diaktualisasikan sebagai inspirasi sprititual bagi tingkah laku kehidupan seseorang atau kelompok dalam bermasyarakat dan bernegara. Yang dibutuhkan umat Islam Indonesia adalah menyatukan “aspirasi islam” menjadi "aspirasi nasional". 34

\footnotetext{
30 Wahid, Pergulatan, 4

31 Abdurrahman Wahid, Universalisme Islam dan Kosmopolitanisme Peradaban Islam, dalam Abdurahman Wahid, Islam Kosmopolitan: Nilai-nilai Indonesia dan Transformasi Kebudayaan, (Jakarta: The Wahid Institute, 2007), 3

32 Abudinata, Filsafat Pendidikan Islam (Jakarta: Logos, 997), 12

33 Greg Barton, “Memahami Abdurrahman Wabid”, dalam kata pengantar Wahid, Prisma Pemikiran, xxxvi

34 Zainal Arifin Thoha, Kenyelenehan Gus Dur Gugatan Kaum Muda NU dan Tantangan Kebudayaan (Yogyakarta: Gama Media, 2001), 205-206 
Konsep yang diusung oleh Gus Dur dalam pribumisasi islam tentunya ingin memberikan cara pandang seseorang dalam mensikapi dan memahami agama tidak hanya dairi luarnya saja, atau dalam hal ini memang datang dari arab, melainkan nilai islam yang perlu ditanamkan dalam kehdiupan sehari-hari. Kalau Islam dimaknasi sebagai agama arab dan mengikuti budaya arab, maka nilai-nilai sosial yang diajarkan oleh Islam akan terasa jadi sempit. Gus Dur hadir ditengahtengah masyarakt untuk memberikan tawaran atau jalan tengah bahwa Islam hadir sebagai rabmatan lil 'alamin sebagai agama yang mampu menanamkan nilainilai sosial dalam kehidupan yang majemuk dan plural.

\section{Diskomposisi Sikap dan Desain Pendidikan Multikultural Gus Dur}

Pendidikan multikultural di tanah air, acapkali, disimbolisasi proses pengenalan dan pembelajaran nilai-nilai perbedaan yang ada di masyarakat; apakah itu dari sisi bahasa, budaya, agama, dan sistem sosial kemasyarakatan lainnya. Tetapi ada hal yang banyak dilupakan oleh banyak kalangan, yaitu makanan yang beragam. Ekspresi dan manifestasi keberagaman dalam makanan semakin memperkukuh entitas khebinekaan yang berwujud dalam bangsa ini. Ketika berkunjung ke tempat manapun, yang paling menarik dan menjadi salah satu kekuatan adalh aneka maca menu makanan dengan varianya. Bahkan, belakangan soal keberagaman makanan tersebut dijadikan salah satu acara di stasiun televisi, yang dikenal dengan wisata kuliner. ${ }^{35}$

Bagi Gus Dur, siapapun yang memahami realitas keragaman masakan di seluruh daerah dan pelosok negeri ini, memahami terhadap wawasan multikulturalisme dengan baik. keragaman masakan sebenarnya merupakan unsur kekuatan, bukan sebuah ancaman. Makanan yang beraneka ragam tersebut menjadi fakta penjelas tentang multikulturalisme merupakan rahmat tuhan yang harus didayagunakan untuk kemajuan bangsa. Belajar dari keragaman makanan, maka kita sebenarnya dapat merayakan manfaat dari multikulturalisme.

35 Maman Imanulhaq Faqih, Fatwa dan Canda Gus Dur (Jakarta: Kompas, 2000), 148 
Sikap Gus Dur yang plural-multikultural bukanlah sebuah ide yang menawarkan semua agama memiliki kesamaan. Harus dipahami bersama bahwa setiap agama mempunyai ajaran yang berbeda-beda. Tetapi perbedaan tersebut bukanlah alasan untuk menebarkan konflik dan perpecahan. Perbedaan seharusnya menjadi katalisator untuk memahami anugerah tuhan yang begitu nyata untuk senantiasa merajut keharmonisan dan toleransi. Oleh sebab itu, perbedaan dan keragaman merupakan keniscayaan yang tidak dapat dihindari. Apalgi dalam perbedaan dan keragaman tersebut tersimpan keistimewaan, yang mana antara kelompok lain bisa saling mengisi dan menyempurnakan. ${ }^{36}$

Setidaknya ada tiga hal mendasar, menurut Gus Dur, yang bisa dilakukan sebagai ikhtiar mengurangi berbagai bentuk ancaman terhadap kemajemukan bangsa, Pertama, penegakan hukum secara tegsa terhadap pelaku tindak kekerasan dan pemaksaan kehendak yang mengatasnamakan agama. Kedua, ormas-ormas keagamaan harus didorong untuk mengedepankan dialog dan kerjasama dalam berbagai bidang sosial dan kebudayaan sehingga toleranso dapat ditumbuhkan secara menyeluruh. Ketiga, nilai-nilai toleransi perlu ditanaamkan dan diajarkan sejak dini dan berkelanjutan kepada anak-anak mulai dari Sekolah Dasar sampai Perguruan Tinggi. ${ }^{37}$

Wajah kebudayaan Indonesia yang bhineka menuntut sikap toleransi yang tinggi dari setiap anggota masyarakat. sikap toleransi tersebut harus dapat diwujudkan oleh semua anggota dan lapisan masyarakat sehingga terbentuklah suatu masyarakat yang kompak tapi beragam sehingga kaya akan ide-ide baru. ${ }^{38}$ Serta hubungan antar agama di Indonesia selama kurun waktu 30 tahun terakhir ini telah berkembang dalam berbagai dimensinya, yang secara kualitatif telah merubah, dan pada saat yang sama dipengaruhi oleh perkembangan pemikiran keagamaan di kalangan umat beragama. Hal ini bisa dilihat dari latar belakang perkembangan Islam yang bentuk dan corak heterogen. Secara garis besar, Islam datang dalambentuk utusan-utusan politik, pedagang dan para sufi. ${ }^{39}$

\footnotetext{
36 Imanulhaq Faqih, Fatwa, 149

37 A. Muhaimin Iskandar, Melanjutkan Pemikiran dan Perjuangan Gus Dur (Yogyakarta: LKiS, 2010), 19-20.

38 Tilaar, Pendidikan, 180.

39 Abdurrahman Wahid, dkk, Dialog: Kritik dan Identitas Agama (Yogyakarta: Pustaka Pelajar, 1993), 3. 
Pluralitas masyarakat Indonesia sendiri sekurang-kurangnya bisa dilihat sebagai fakta dalam dua sisi. Sisi pertama, pluralitas suku, agama dan budaya serta turunannya. Sisi kedua, pluralitas di internal suku, agama dan budaya itu sendiri. Dalam islam misalnya, terdapat beberapa aliran yang secara formal seringkali berseberangan. Toleransi yang diajarkan Gus Dur merupakan ajaran semua agama dan budaya, apalagi dalam masyarakat yang majemukdan multikultur Indonesia. namun, toleransi yang diajarkan dan dipraktikan Gus Dur berbeda dari tokoh agama lain. ajarannya bersifat toleransi yang tidak hanya menginginkan orang membudayakan hidup berdampingan dengan damai, yaitu hidup bersama dalam suasana ssaling menghormati dan menghargai. Tidak demikian dengan Gus Dur. Dalam menyikapi pluralitas tersebut, Gus Dur menegaskan bahwa tegaknya paham multikultural pada masyarakat bukan hanya terletak pada pola hidup berdampingan secara damai, karena hal demikian masih sangat rentan terhadap munculnya kesalahpahaman antar kelompok masyarakat yang pada saat tertentu bisa menimbulkan disintegrasi. Lbih daripada itu, penghargaan terhadap keberagaman berarti adanya kesadaran untuk saling mengenal dan berdialog secara tulus sehingga kelompok yang satu dengan lain bisa saling memberi dan menerima. ${ }^{40}$

Meskipun masih ada beberapa elemen bangsa yang mempermasalahkan konsep multikulturalisme di Indonesia, salah satu penyebabnya adalah ketidakthuan terhadap sejarah lahirnya bangsa Indonesia. salah satu cara mengatasinya, kata Gus Dur, bangsa Indonesia harus meambangun batasan bersama. Batasan itu berupa penghargaan terhadap multikultural tidak akan diutak atik. Batasan ini juga berlaku saat membahas Undang-Undang Dasar Negara. ${ }^{41}$ Konsep toleransi yang dikembangkan Gus Dur meniscayakan adanya kebenaran yang datang dari agama atau peradaban lain. namun, jika kerendahan hati seperti ini bisaa dikembangkan ssecara terus menerus, maka toleransi di tengah masyarakat, akan semakin menemukan polanya yang dengan sendirinya kerukunan antar umat beragama akan menjadi bagian tak terpisahkan dari dinamika masyarakt dan suasana saling belajar,

40 M. Hanif Dhakiri, 41 Warisan Kebesaran Warisan Kebesaran Gus Dur (Yogyakarta: LKiS, 2010), 120

${ }^{41}$ Catatan Akhir Tahun 2008 Gus Dur, Pluralisme di Indonesia Mengalami Krisis, http://wahidinstitute.org, diakses pada 14 Mei 2017. 
melengkapi dan mengisi akan menciptakan kultur keberagamaan yang matang dan dewasa. Jika sudah demikian, maka dengan sendirinya perbedaan agama dan keyakinan akan menjadi sumber kekuata yang dahsyat bagi perubahan dalam persaudaraan.

Kepedulian Gus Dur terhadap kasus-kasus Internasional yang beberapa diantaranya kontroversial termasuk hubungannya dengan Israel, maupun kasus kekerasan etnik dan keagamaan serta kasus yang berkaitan dengan HAM dan demokrasi di Indonesia, misalnya: persoalan Ahmadiyah, ICMI, Ulil Abshar Abdalla, peristiwa Banyuwangi, kasus Inul, peristiwa di Ambon, persoalan etnis Cina, tidak hanya dibuktikan pada level pemikiran saja, akan tetapi selalu tampil sebagai pembela pada level praktis. Dari pembacaan naratif di atas, penulis dapat membingkai kerangka pemikiran dan sikap Gus Dur dalam konteks pendidikan multikultural adalah sebagaimana berikut:

\section{Bagan 1.1}

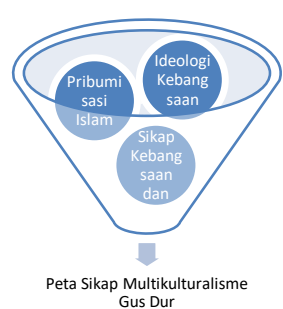

Pada level pertama, keyakinan dan kemantapan diri Gus Dur untuk menyebut Indonesia sebagai negara multikultural tidak bisa dilepaskan dari sikapnya yang mendahulukan kepentingan kebangsaan dibandingkan kepentingan indvidu atau kelompok tertentu. Hal ini sebagai peneguhan untuk memperlakukan ideologi kebangsaan sebagai keutuhan pandangan dan cita-cita, yang menghimpun semua kekayaan hidup bangsa dalam sebuah kekuatan dahsyat dalam mempertahankan negara dan mencapai tujuan yang diinginkan bagi kesejahteraan warga negara Indonesia.

Level kedua, pribumisasi pendidikan Islam merupakan salah satu ide Gus Dur yang masih hangat hingga saat ini. Gus Dur menginginkan pola pemahaman 
pendidikan tidak terlepas dari budaya dan tradisi yang sudah ada. Dengan demikian, Gus Dur menginginkan perlu adanya kesadaran struktural sebagai bagian alamiah dari perkembangan pendidikan Islam.

Level ketiga, dengan kondisi bangsa Indonesia yang majemuk, nilai-nilai serta sikap Gus Dur tidak terlepas dari kondisi sosio-intelektual yang melingkupinya. Sehingga tergambarkan melalui pemikirannya serta sikap yang ditunjukan ketika ada peristiwa genting seperti pelanggaran HAM, intoleransi paham keagamaan, serta penindasan terhadap kaum minoritas.

Pribumisasi Pendidikan Islam merupakan hasil dari proses pergumulan dan pergulatan terhadap pemahaman Pendidikan Agama yang sangat Normatif. Meminjam pendekatan dari Amin Abdullah, normativitas dan historisitas membuat pendidikan Islam menjadi sangat kaku, seakan-akan pendidikan kita harus seperti pendidikan yang ada di Arab, di mana Islam lahir dari jazirah tersebut. Padahal, bila kita cermati masuknya Islam dan belajarnya masyarakat nusantara di Jawa dalam melakukan pendidikan Islam itu banyak menggunakan pendekatan budaya lokal. Budaya lokal merupakan akar historis yang dipertimbangkan dalam pendidikan islam. Islam bukan lagi diajarkan dengan normativitas melainkan diajarkan dengan historisitas yang memakai pendekatan pribumisasi pendidikan Islam.

Berkaitan dengan ide pribumisasi Islam, Gus Dur berargumen bahwa agama Islam dan budaya mempunyai independensi masing-masing, akan tetapi keduanya mempunyai wilayah yang tumpang tindih. Agama Islam bersumberkan wahyu dan memiliki normanya sendiri. Karena bersifat normativ, maka ia cenderung permanen, sedangkan budaya adlah buatan manusia, karena ia berkembangn sesuai dengan perkembangan zaman dan cenderung untuk selalu berubah. Perbedaan ini tidak menghalangi kemungkinan manifestasi kehidupan beragama dalambentuk budaya. Di sinilah adanya akomodasi atau rekonsiliasi. Proses itu harus dilakukan secara alami, bukan terpaksa dan itulah proses alami dari pribumisasi. ${ }^{42}$

Proses pertumbuhan Islam sejak masa Nabi Muhammad, sahabat, para ulama tidak serta merta menolak seluruh tradisi pra-Islam (dalam hal ini budaya masyarakat

42 Abdurrahman Wahid, Islam Indonesia Menatap Masa Depan, Kata Pengantar M. Dawam Raharjo (Jakarta: P3M, 1989), 332 
Arab pra Islam). Tidak seluruh sistem lokal ditolak Islam, tradisi dan adat setempat yang tidak bertentangan secara diametral dengan Islam dapat dinternalisasikna menjadi ciri khas dari fenomena islam di tempat tertentu. ${ }^{43}$ Demikian juga proses pertumbuhan Islam di Indonessia tidak dapat lepas dari budaya dan tradisi masyarakat.

Gagasan Gus Dur ini tampaknya ingin memperlihatkan Islam sebagai sebuah agama yang apresiatif terhadap konteks-konteks lokal dengan tetap menjaga pada realias pluralisme kebudayaan yang ada (multikulturalisme). Gus Dur dengan tegas menolak "satu Islam" dalam ekspresi kebudayaan. Misalnya, semua simbol atau identitas harus menggunakan ekspresi kebudayaan Arab. Penyeragaman yang terjadi bukan hanya akan mematikan kreatifitas kebudayaan umat tetapi juga membuat Islam teralienasi dari arus utama kebudayaan nasional. ${ }^{44}$ Ide pribumisasi yang digagas oleh Gus Dur sangat relevan sekali dengan fokus dari pendidikan multikultul itu sendiri. Sebagaimana yang diuraikan oleh Tilaar bahwa program pendidikan multikultural tidak lagi fokus kepada kelompok rasial, agama dan kultural domain atau mainstream. Melainkan merupakan sikap peduli dan mau mengerti (difference) atau politik pengakuan terhadap orang-orang dari kelompok minoritas. ${ }^{45}$

Dalam perkembangan dasawarsa terakhir, masyarakat muslim lebih bersifat pada kecenderungan memahami Islam dengan normativitas dan itu bergulat dengan tantangan modernitas. Di satu sisi, dan kondisi objektif umat Islam pada sisi lainnya. Secara mendasar, ada dua arus besar dalam memahami agama yang berkembang, pertama, adalah kecenderungan beragama dan memahami pendidikan Islam yang mengandaikan umat sebagai konsumen pemahaman agama atau konsumen pendidikan Islam, sedangkan elit agama sebagai sebuah produsen sumber pemhaman pendidikan Islam di masyarakat. Menurut Gus Dur, pola pendidikan seperti ini adalah kelompok Islam yang totalistik atau islam alternatif, ${ }^{46}$ dalam memahami pendidikan agama dan pemahaman agama. Kelompok yang menginginkan

\footnotetext{
43 Umar, Membaca, 141

44 Wahid, Pergulatan, 119

45 Azyumardi Azra, "Identitas dan Krisis Budaya, Membangun Multikulturalisme Indonesia", dalam http:/budpar.go.id/agenda/precongress/makalah/abstrak/58\%20azra.htm, diakses 15 Juni 2017.

46 Abdurrahman Wahid, Tuban Tidak Perlu Dibela (Yogyakarta: LkiS, 2002), 17

114 | Tarbiyatuna: Jurnal Pendidikan Islam; Volume 11, Nomor 1, Februari 2018 p-ISSN: 2085-6539, e-ISSN: 2242-4579
} 
"islamisasi” yakni pada aktifitas yang paling awal dirumuskan ukuran normativitasnya pada berbagai bidang pendidikan, termasuk dalam aspek material seperti teori sosial, sistem politik, sistem ekonomi, bahkan sampai pada cara komunikasi dalam kehidupan harus menggunakan pendekatan fiqih, yang melihat segalanya dalam pandangan serba dikotomis, dualisme world view, yakni halal haram, surga-neraka, salah benar dan seterusnya.

Pola pemahaman dan pembelajaran pendidikan seperti ini karena didasari oleh kekhawatiran terhadap ancaman imperialisme Barat yang tidak memberikan masa depan terhadap agama. ${ }^{47}$ Tegasnya, modernitas itu ditandai dengan adanya globalisasi dan sekularisasi dalam setiap aspek kehidupan manusia. dianggapa telah merongrong kelangsungan identitas tradisional dan nilai-nilai agama. Di sisi lain, kecemasan kelompok ini adalah karena dalam linkungan Islam sendiri ada sekelompok orang Islam yang melenceng dari ketentuan syari'at Islam. ${ }^{48}$

Kedua, pemahaman agama dan pendidikan agama Islam yang mengarah pada paradigma modernisasi, bertolak dari sebuah kepedulian atas keterbelakangan dan ketertinggalan umat Islam dibandingan dengna kemajuan yang digapai oleh Barat. Ketertinggalan islam dalam memahami masalah pendidikan Islam karena ketertutupan pemahaman dan ajaran agama Islam itu sendiri. Pendidikan yang baik adlah pendidikan yang berani mendialigkan kemajuan zaman dengan budaya lokal dan dibarengi sikap kritis terhadap budaya dan proses modernisasi. Bagi golongan ini, ambisi yang dilakukan adalah mengambil subtansi nilai-nilai keislaman dan tidak berupaya mengislamkan apa yang dulunya belum Islam, misalnya pendidikan yang berasal dari Barat yang dalam pandangan "golongan pertama" perlu diislamkan, melainkan dengan mendialogkan dengan apa yang ada di dalam masyarakat.

Kontruksi pribumisasi pendidikan Islam adalah sebagai sebuah kritik terhadap cara pendidikan Agama Islam yang lebih pada normativitas keagamaan bukan pada pengajaran nilai-nilai pendidikan Islam yang akan menjawab akar kekeringan pendidikan agama dari nilai-nilai agama itu sendiri. Proses yang dibangun oleh Gus Dur merupakan proses dehumanisasi pendidikan Islam, yang menitik

\footnotetext{
${ }^{47}$ Wahid, Tuhan, 109

${ }^{48}$ Bactiar Efendi, "Mengembangkan Konsep Depriative Agama," dalam Jurnal Ulumul al Qur'an, No. 3, 1997, 44 
beratkan kepada pendidikan berkembang dalam ruang dan nilai yang diajarkan di dalam masyarakat bukan hanya dalam pendidikan formal yang dalam kesehariannya sebagai sistem "pendidikan dengar" melainkan dalam kaidah pendidikan bermakna.

Sikap Gus Dur tidak hanya menjadi agamawan yang mengajarkan agama Islam kepada umat manusia. Akan tetapi juga mengajarkan sikap santun, ramah, toleran terhadap semua masyarakat. Ada dua model humanisme yang diajarkan Gus Dur berkaitan dengan sikapnya tersebut. Pertama, sumbangan agama Islam bagi humanisme ala Gus Dur adalah humanisme Islam yang antitesis dari humanisme atheis. Dalam menngupayakan pendidikan agama yang humanis, Gus Dur selalu menekankan subntansi agama berupa nilai-nilai agama bukan normativitas agama yang dibungkus oleh kesejahteraan masyarakat, toleransi persamaan di muka hukum, demokrasi, dan toleransi antar agama. Kedua, sumbangsih pemikiran Gus Dur dalam pribumisasi pendidikan Islam adalah mengajarkan agama Islam yang toleran. Hal ini dapat dilihar ketika Gus Dur menjadi Presiden Republik Indonesia dengan mengeluarkan aturan yang sekrang dapat dirasakan manfaatnya oleh masyaraat terutama bagi warga Thionghoa seprti hari raya Imlek dijadikan hari libur nasional, dan keputusan-keputusan lainnya.

Benar seperti apa yang dikatakan oleh Greg Barton bahwa Gus Dur merupakan seorang tokoh yang cinta terhadap budaya Islam Tradisional (dalam hal ini khazanah pemikiran Islam yang dihasilkan oleh ulama-ulama terdahulu). Namun kecintaanya ini bukan berarti keterlibatan dan penerimaan segala aspek budaya tradisional karena Gus Dur sangat kritis terhadap budaya tradisional. ${ }^{49}$ Konsep pribumisasi Islam yang diusung oleh Gus Dur tentunya ingin memberikan cara pandang seseorang dalam mensikapi dan memahami agama tidak hanya dari luarnya saja, atau dalam hal ini Islam memang datang dari negara Arab akan tetapi nilai Islam yang perlu ditanamkan dalam kehidupan sehari-hari, bukan budaya Arab yang harus disamaratakan dan diterapkan dalam kehidupan beragama. Kalau Islam dimaknai sebagai agama Arab dan mengikuti budaya Arab, maka nilai-nilai sosial yang diajarkan oleh Islam akan terasa menjadi sempit. Gus Dur hadir ditengah-tengah masyarakt

${ }^{49}$ Greg Barton, "Memahami Abdurrahman Wabid", dalam pengantar Wahid, Prisma, xxxvi. 
untuk memberi jalan tengah bahwa Islam hadir ssebagai rahmatal lil 'alamin sebagai agama yang mampu menanamkan nilai-nilai sosial dalam kehidupan yang majemuk dan plural.

Dalam konteks keindonesiaan yang pluralistik, Islam hendaknya tidak ditempatkan sebagai ideologi alternatif seperti memposisikan syari'ah berhadapan dengan kedaulatan rakyat. Kontribusi Islam dalam demokrasi bisa dicapai bila dari Islam ditarik sejumlah prinsip universal seperti persamaan, keadilan, musyawarah, kebebasan dan rule of law, karena dalam satu aspeknya adalah merupakan hukum agama. Pemikiran demokrasi Gus Dur ini menunjukkan sikap ideologis karena menerima konsep demokrasi liberal atau parlimenter dan secra tegas menolak pemikiran atau kedaulatan Tuhan atau pemikiran yang berusaha mengawinkan kedaulatan Tuhan dengan kedaulatan rakyat.

Zuhairi Misrawi melihat bahwa Gus dur telah memperlakukan kelompokkelompok minoritas, terutama mereka yang tertindas, sebagai warga negara yang mempunyai hak sama di depan hukum. Sehingga, pemikiran tentang multikulturalisme sejalan dengan spirit demokrasi, bahkan makin memperkukuh. Keduanya tidak bertentangan, malah saling menguatkan. ${ }^{50}$ Menurut Gus Dur, demokrasi hanya bisa dibangun di atas landasan pendidikan yang kuat, dengan ditopang oleh tingkat kesejahteraan ekonomi yang memadai. Gus Dur menggunakan pendekatan cultural politics dalam meretas jalan demokrasi. Mengenai hubungan demokrasi dan Islam, Gus Dur sampai pada pemahaman bahwa Islam dan pola implementasinya dalam konteks negara dan bangsa, sangat memperhatikan konteks politik dan sosiologis suatu bangsa dan masyarakat. karena ia lebih menekankan subtansi ajaran Islam daripada simbol-simbol formalnya.

Menghidupkan dan mengembangkan kembali pemikiran Gus Dur dewasa ini masih sangat relevan. Diantaranya diperlukan pandangan keagamaan yang berorientas kebangsaan, yang dapat melindungi seluruh warga negara, apapu agama, keyakinan, kelompok, ras dan sukunya. Dalam buku, Islamku, Islam Anda dan Islam Kita, Gus Dur menegaskan bahwa umat Islam Indonesia harus mengembangkan pandangan

50 Zuhairi Misrawi, "Pluralisme Pasca Gus Dur” dalam Sejuta Gelar Untuk Gus Dur (Jakarta: Pensil, 2010), 88. 
keislaman yang berorientasi kebangsaan. Salah satu pesan yang sangat kuat dalam al Qur'an adalah bahwa Nabi Muhammad Saw. diutus oleh Tuhan untuk membangun persaudaraan bagi seluruh umat. ${ }^{51}$

Istilah tersebut, munurut Zuhairi Misrawi, menjadi salah satu prinsip yang sangat menonjol di lingkungan NU, yaitu Islam sebagai rabmatal lil 'alamin. Islam menyebarkan ajaran tentang perdamaian dan toleransi, bukan ajaran yang menebarkan konflik, apalagi kekerasan. Gus Dur selalu menyatakan bhwa keberislaman yang berkembang di Arab Saudi, berberda dengan islam yang berkmebang di Indonesia. Interaksi kebudayaan di antara berbagai kelompok di Indonesia telah menjadikan Islam sebagai agama yang terbuka terhadap perbedaan dan keragaman, bahkan mendorong demokratisasi. ${ }^{52}$

Ada dua hal penting yang harus diperhatikan berkenaan dengan sikap ideologis dan kultural pada dua cabang dalam kehidupan agama. Pertama, Gus Dur sendiri berpendapat bahwa perbedaan agama-agama cenderung merupakan perbedaan yang berada dalam tataran kemanusiaan. Dia mengatakan bahwa sesungguhnya yang menjadi hakim untuk mengatakan seseorang masuk surga dan neraka adalah tuhan sendiri. ${ }^{53}$ Baik agamawan, rohaniawan, kiai, muballigh, atau wali sekalipun tidak bisa melakukan judgment atau penghakiman kepada orang selama di dunia. Karena Gus Dur sadar bahwa ada banyak hal tersembunyi dalam kehidupan seseorang selama hidup di dunia ini, dan itu hanya Tuhan yang tahu. Oleh sebab itu, maka tuhanlah yang akan menentukan apakah seseorang itu benar atau salah di hari akhir nanti. Kedua, Gus Dur juga melangkah pada segi-segi yang lebih praktis. Bagi Gus Dur, praksis agama menjadi sesuatu yang esensial di dalah hubungan antar agama yang didasari oleh toleransi dan langkah yang sangat konkrit. Sebagai bukti, Gus Dur melakukan kerjasama degan siapa saja secara terbuka, baik dalam kelompok Kristen, Hindu, Budha, maupun kelompok Islam yang lain. meski kemudian banyak berhubungan dengan kelompok-kelompok sekuler yang tidak terlalu banyak

\footnotetext{
51 QS. al Anbiya': 107)

52 Misrawi, Pluralisme, 91

53 Tim INCReS, Beyond The Symbol: Jejak. Antropologis Pemikiran dan Gerakan Gus Dur (Bandung: PT. Remaja Rosdakarya, 2000), 108

118 | Tarbiyatuna: Jurnal Pendidikan Islam; Volume 11, Nomor 1, Februari 2018 p-ISSN: 2085-6539, e-ISSN: 2242-4579
} 
mempersoalkan doktrin-doktrin atau dogma-dogma agama adalah perkembangan lain. $^{54}$

Ada satu agenda penting yang terus dilakukan Gus Dur hingga akhir hayat yakni penghormatannya terhadap agama lain dengan tujuan mengukuhkan dan meneguhkan NKRI. Pemikiran ini dapat dilacak tatkala Gus Dur menjabat sebagai ketua umum Pengurus Besar Nahdlatul Ulama' (PBNU). Ia tidak hanya melakukan reformasi di tubuh PBNU, tetapi juga bersama KH. Ahmad Siddiq melakukan proses transformasi pemahaman bahwa Pancasila adalah titik kompromi yang sudah tepat dan final dalam membangun tata kehidupan yang majjemuk dan beragam di Indonesia. Dalam konteks ini, NU menjadi organisasi sosial keagamaan pertama yang menerima ideologi Pancasila sebagai asas tunggalnya. Perjuangan Gus Dur bagi NKRI menjadi prinsip dasarnya, sehingga ia selalu menaruh perhatian besar terhadap Bhineka Tunggal Ika sebagai bentuk multikulturalisme. Perjuangan bagi tegaknya NKRI menjadi kunci utama setiap pemikiran dan gerakannya. ${ }^{55}$

Menurut Gus Dur, salah satu bentuk Islam yang universal tercermin dalam konsep kepedulian Islam yang sangat besar kepada unsur kemanusiaan. Prinsipprinsip seperti persamaan derajat dimuka umum, perlindungan warga masyarakat dari kedlaliman dan kesewenang-wenangan, penjagaan hak-hak mereka yang lemah dan menderita kekurangan serta pembatasan atas wewenang para pemegang kekuasaan. ${ }^{56}$ Salah satu ajaran yang dengn sempurna menampilkan universalisme Islam adalah lima buah jaminan dasar yang diberikan agama samawi terahir ini kepada masyarakat, baik secara perorangan maupun sebagai kelompok. Kelima jaminan dasar ini terseba r di dalam literatur hukum agama (al kutub al fiqhiyyah)lama, yaitu jaminan dasar akan; keselamatan fisik, keselamatn keyakinan agama, keselamatan keluarga, keselamatan harta benda, dan keselematan profesi.

54 INCReS, Beyond The Symbol, 109.

55 Muhammad Rifa'i, Gus Dur, KH. Abdurrahman Wabid Biografi Singkat 1940-2009 (Jakarta: Ar-Ruzz Media, 2010)

56 Wahid, Islam Kosmopolitan, 4-5. 


\section{Desain Sistemik Pendidikan Islam Multikultural Gus Dur; Analisa Teori Sistem}

Sebelum penulis melakukan analisa berbasis sistem, sesuai dengan kerangka teori yang penulis ajukan untuk membingkai ulang topik pada riset ini. Tentu ada baiknya penulis mengakui terlebih dahulu beberapa hal penting yang harus digaris bawahi dalam riset ini; pertama, keberadaan pendidikan (Islam) multikultural hanyalah sebuah diskursus ideal yang dilahirkan daripada kajian akademik. Namun, pada proses implementasinya, konsep ini tidak terlihat sebagai basis utama sistem pendidikan nasional. Argumentasinya, mungkin, bagi sebagian kalangan, pendidikan multikultural pada definisi idealnya, masih bertentangan dengan kondisi budaya Indonesia. Artinya, amalgamasi (perkawinan) kebudayaan yang diusulkan pendidikan multikultural tidak bisa menyentuh basis keyakinan teologis umat Islam sebagai agama mayoritas. Jadi, sebagai sebuah diskursus, pendidikan multikultural bisa dikatakan ideal untuk Indonesia. Tapi, dalam tarap implementasi masih banyak hal yang harus dipertimbangkan, misalnya; mampukah lembaga pendidikan menghadirkan truth-exchange pada bingkai perbedaan pandangan di internal atau eksternal umat beragama.

Kedua, Gus Dur - dalam konteks penelitian - sebenarnya tidak penulis posisikan sebagai penggagas konsep Pendidikan Islam Multikultural. Pasalnya, penulis tidak bisa menghadirkan karya spesifik Gus Dur yang terelasi langsung dengan pendidikan multikultural. Walaupun, dalam konteks kajian akademik, penulis diwajibkan 'bisa dan memungkinkan' untuk membangun postulasi tersendiri agar menceritakan bagaimana Gus Dur bisa dijadikan inspirasi ideal dalam konteks pendidikan Islam Multikultural, laiknya beberapa penelitian terdahulu, yang sudah penulis sebutkan sebelumnya. Ketiga, pada posisi perumusan postulasi ini, penulis mengambil posisi sebagai pembaca sikap ideologis dan cultural Gus Dur yang dia tampakkan pada karya akademik, opini, dan pemberitaan yang ditulis oleh wartawan, dalam merespon peroblematika multikulturalisme yang ada di Indonesia. Keempat, dari dua sikap dan penegasan rasional Gus Dur tersebutlah, penulis berkeyakinan, bahwa potret pendidikan (Islam) multikultural ideal bisa dilihat dari sosok Gus Dur. Kelima, 
untuk mendisiminasikan sikap tersebut, maka penulis 'meminta bantuan' teori sistem untuk mengkonstruk postulat tersebut.

Sebagaimana diketahui, teori sistem acapkali dimaknai sebagai sebuah rangkaian yang saling terikat untuk sampai pada tujuan akhirnya. Atau dalam bahasa lain disebutkan bahwa sistem adalah sehimpunan unsur yang melakukan sesuatu kegiatan, atau menyusun skema atau tata cara melakukan sesuatu kegiatan pemrosesan untuk mencapai sesuatu atau beberapa tujuan, dan hal ini dilakukan dengan cara mengolah data dan/atau energi dan/atau barang (benda) di dalam jangka waktu tertentu guna menghasilkan informasi dan/atau energi dan/atau barang (benda). Pada intinya, sistem adalah sebuah piranti yang memiliki tugas spesifik, yang terkumpul dalam suatu space, untuk mencapai tujuan yang sudah direncanakan. Adapun sistem dalam konteks pendidikan selalu diartikan sebagai perangkat input, proses, dan output, atau yang lebih detail adalah terbentuknya tujuan, masukan, proses, keluaran, mikanisme, dan evaluasi terhadap alur pendidikan yang sudah ditentukan tersebut.

Dalam diskursi pendidikan multikultural, piranti sistem yang dimaksudkan secara ideal - adalah sebagaimana terbingkai dalam bagan berikut:

\section{Bagan 2.1}

\section{Bagan Sistem Pendidikan Multikultural Indonesia}

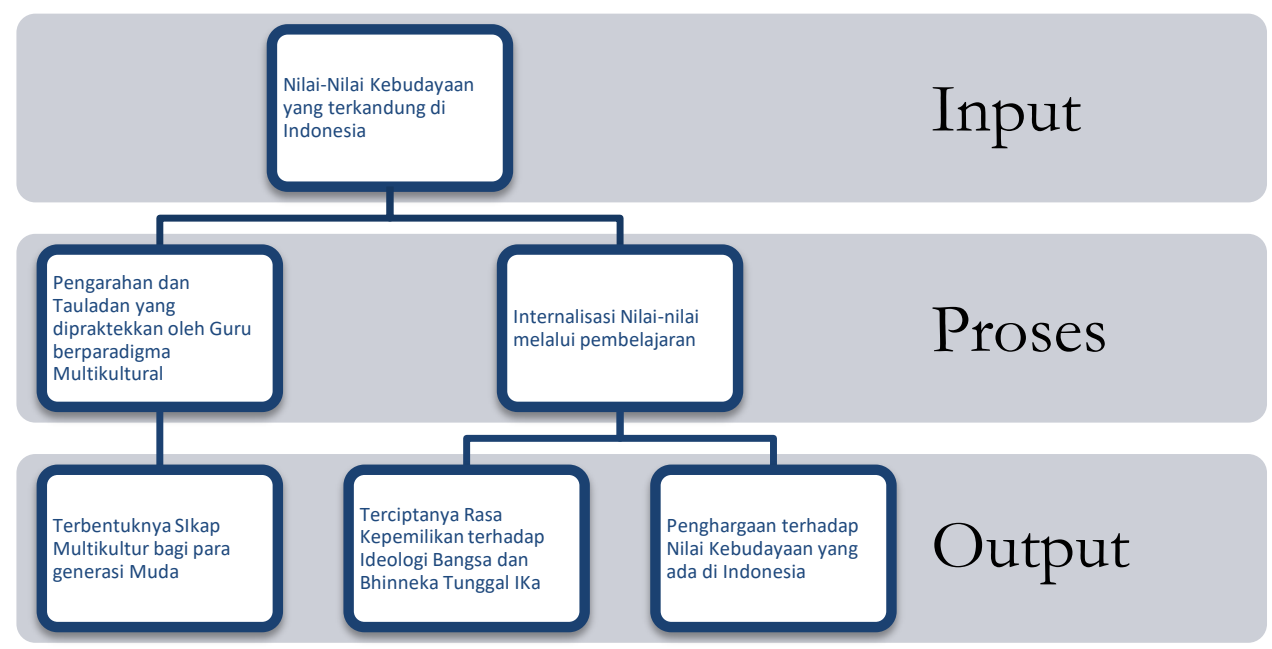


Sebagaimana bagan di atas, HAR Tilaar, meski sedikit menyederhanakan proses, dia mengusulkan bahwa representasi pendidikan multikultural di Indonesia melalui proses pembelajaran PKn (civic education). Padahal, kontestasi yang ada di Indonesia, tidak selalu ter-challenge dari aspek kebudayaan social-kemasyarakatan. Hal yang lebih kompleks dari itu adalah problematika terbenturnya sikap keberagamaan dan keberagaman yang ada di Indonesia. Oleh karenanya, sebagaimana diskompisisi sebelumnya, penulis beranggapan bahwa kerangka berfikir sistem pendidikan multikultural yang ideal adalah seperti yang dilakukan oleh Gus Dur. Bagan berikut ini bisa menunjukkan bagaimana sikap Gus Dur, konstruksi ideal pendidikan multikultural yang semestinya dilaksanakan di Indonesia, khususnya berhubungan dengan benturan agama, negara, dan kebudayaan yang ada di Indonesia;

Bagan 3.1

Kerangka Sistemik Pendidikan Islam Multikultural Gus Dur

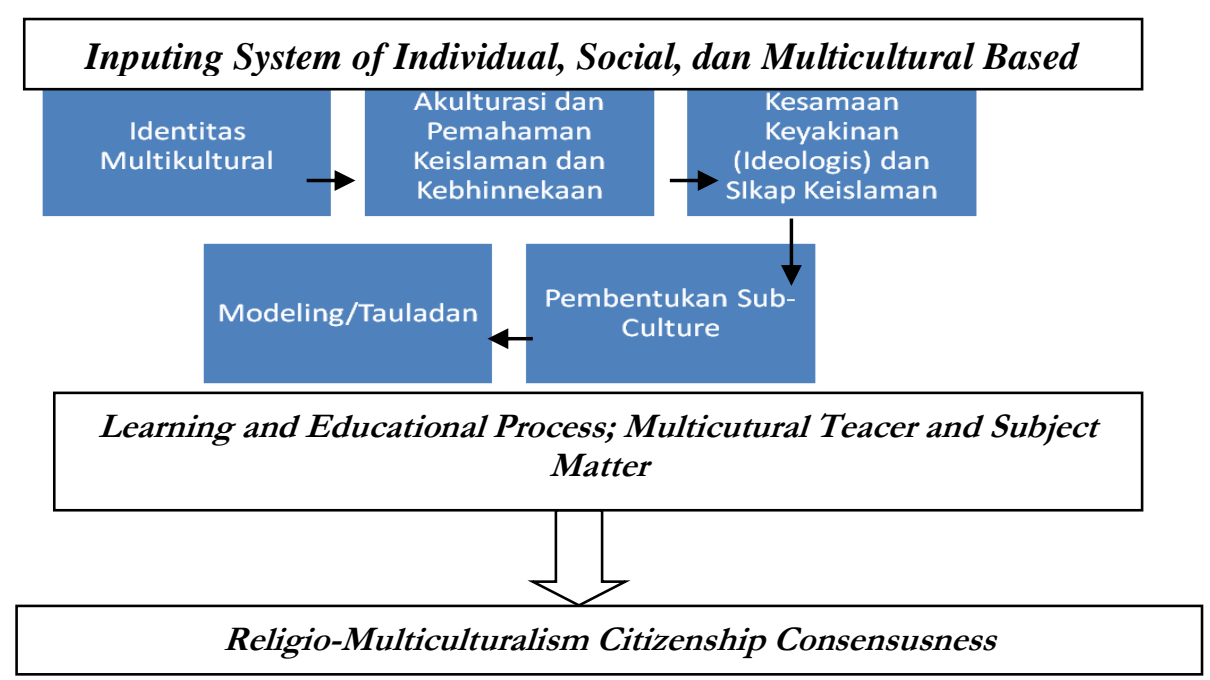

Bagan di atas, secara bagan tersebut bisa dimaknai sebagaimana berikut; pertama, Gus Dur menganggap bahwa keberadaan multikulturalisme di Indonsia sebagai identitas, sudah berjalan lama dan dipegang teguh oleh masyarakat Indonesia, tanpa mampu memaknainya secara baik. Kedua, keberadaan tersebut kemudian sedikit 
terusik ketika keberadaan Islam di Indonesia. Islam - termasuk semua agama yang lain - selalu membawa nilai-nilai baru di dalam kehidupan masyarakat. Maka dari itu, Gus Dur (termasuk yang ditunjukkan para walisongo, kyai, dan cendikiawan muslim lainnya) lebih memilih untuk menakulturasi nilai-nilai keislaman, menjadi bagian dari kehidupan subtantif masyarakat. Islam tidak dihadirkan sebagai counter-culture yang bisa merusak fondasi keragaman di Indonesia. Ketiga, pilihan rasional dan amalgamative yang harus dipegang teguh oleh masyarakat melalui ideology Pancasila. Pancasila, dalam segala kekurangan interpretasi yang disangkakan, tentu harus direideologisasi, karena tantangan sosialnya berubah. Namun, merubahnya bukanlah pilihan yang tepat. Gus Dur berada dalam posisi ini untuk terus mengkampanyekan Islam dan Nasionalisme tidak bertentang dan terangkum dalam ideology Pancasila yang mengikat multikulturalisme.

Keempat, pembentukan sub-culture di dalam cakupan yang lebih mikro. Kelima, menghadirkan tauladan yang konsisten untuk bersikap ideologis dan multikultural di kalangan masyarakat. Semua proses yang ada di table sismtem hirarkis pertama, dimaksudkan oleh peneliti untuk membentuk input dari luar proses pendidikan. Sebab, sebagaimana diketahui, kontestasi ideologis; apakah itu dulu dan sekarang, berasal dan bermuara dari dimensi luar lembaga pendidikan. Misalnya, kontestasi ideology baru hari akibat dari perdebatan politik. Sebagaimana diketahui, kondisi politik hari ini sudah menampilkan ulang konflik lama; antara kelompok nasionalis dan islamis. Hal ini akan menggangu konstruksi proses yang akan dijalankan di lembaga pendidikan di Indonesia, apalagi dilembaga pendidikan Islam.

Setelah terbentuk konstruksi input (yang tertampil dalam kondisi masyarakat luas, laiknya Gus Dur menampakkan dan menampilkan dirinya sebagai ikon pluralisme) barulah lembaga pendidikan memiliki tanggung jawab untuk melakukan penguatan, peneladanan lebih lanjut, hingga rasionalisasi terhadap sikap-sikap yang tertampil di luar sekolah (social-system appreances as core-tasking mother or booting system). Jadi, lembaga pendidikan hanya sebatas piranti sistem pembentuk; apakah itu dari guru, atau pembelajaran PKn berbasis Islam, atau PAI berbasis wawasan nasionalisme, sebagaimana banyak digagas akhir-akhir ini. Betapapun, dalam anggapan penulis, lembaga pendidikan tidak akan pernah tertampil multikultural, 
khususnya agama, apabila pembedaan-pembedaan terus terjadi di dalam masyarakat. Sekaligus, hal ini akan memberatkan tugas lembaga pendidikan untuk menawarkan kerangka ideal pendidikan multikutural. Kalau semua orang mau belajar dair Gus Dur, dan bagaimana dia dididik di lingkungannya, maka semua orang bisa melihat bagaimana Gus Dur sering melihat ayahandanya berkenalan dengan orang beda agama, suku, budaya, dan bahasa. Gus Dur juga, kala sudah dewasa, berkumpul dan bersosialisas dengan masyarakat yang sangat beragam. Maka, jika tampilan pribadi Gus Dur yang peduli terhadap orang lain, itu adalah bagian dari konstruk yang ada di lingkungannya.

\section{Penutup}

Terakhir, pastinya, pendidikan Islam multikultural ala Gus Dur adalah mencipta masyarakat yang sadar akan multi-etnis di Indonesia. Multi Agama di Indonesia. Multi Budaya di Indonesia. Dengan memproyeksikan tidak sekedar pada basis penerimaan saja. Melainkan kesadaran penuh bahwa Indonesia sudah dicipta beragam. Dikonsiliasikan dan diasimilasikan dengan keislaman yang khas. Dikombinasikan dengan kebudayaan-kebudayaan yang ada di dalam Indonesia. Hingga menjadikan Pancasila dan Bhinneka Tunggal sebagai pengikat ideal masyarakat Indonesia. Bukan lagi agama, melainkan ideology dan kebudayaan yang diciptakan sendiri. Dari semua ulasan ini, maka menurut penulis, rancang utama pendidikan Islam Multikultural dari perspektif Gus Dur dapat dilihat dari tiga aspek penting, sebagaimana yang sudah disebutkan sebelumnya, dan bisa tertransmisikan melalui sudut pandang sistem yang didukung penuh oleh kondisi social. Maka dari itu, keberadaan pendidikan multikultural akan sangat ideal apabila terangkum dalam outer-culture yang dapat dijadikan basis penguat, ideology kebangsaan yang tidak diperdebatkan kembali, dan nilai-nilai subtantif yang bisa diambil dari sejarah, ajaran, dan diksi asimilatif kebudayaan antara Islam dan nilai-nilai kearifan lokal. Kondisi ini tentu akan berbeda dengan negara Eropa dan Amerika yang multukulturalisme cenderung dibentuk, dibandingkan pemberian. Sejarah Amerika membuktikan bahwa mereka selalu menyebut "I am American" untuk menghilangkan konflik sejarah etnis 
hitam (penduduk asli amerika) dan putih (penduduk pendatang). Amerika sejatinya, tidak memiliki kompleksitas problem keagamaan. Nilai-nilai keagamaan sudah dikikis habis, setelah sekularisme menjadi ideology mereka. Maka dari itu, orang Indonesia harus setuju dengan sebutan "Saya Indonesia, Saya Pancasila”. Saya Indonesia adalah identitas pemberian yan multikultural sejak lahir. Dan Pancasila adalah perkawinan antara nilai-nilai lama yang bergabung dengan kebudayaan asli Indonesia.

\section{Referensi}

Abdurrahman Wahid, “Gus Dur dan Gagasan Pancasila sebagai Ideologi Negara”, nuonline.or.id pada tanggal 23 Maret 2017

Abdurrahman Wahid, "Gus Dur tegaskan Pancasila Sudah Final", Surabaya.tribunnews.com pada tanggal 23 maret 2017

Abdurrahman Wahid, "Gus Dur, Rhoma, dan goyang ngebor", merdeka.com pada tanggal 23 maret 2017

Abdurrahman Wahid, Universialisme Islam dan Kosmopolitanisme Peradaban Islam, Jakarta: The Wahid Institute, 2007.

Azyumardi Azra, "Identitas dan Krisis Budaya, Membangun Multikulturalisme Indonesia", dalam http:/budpar.go.id/agenda/precongress/makalah/abstrak/58\%20azra.htm, diakses 15 Juni 2017.

Azyumardi Azra, "Pendidikan Agama: Membangun Multikulturalisme Indonesia" Kata Pengantar dalam Zakiyuddin Baidhawy, Pendidikan Agama Berwawasan Multikultural, Surabaya: Impulse, 2004.

Baker, G.C., Planning and Organizing for Multicultural Instruction. (2), California: AddisonElsey Publishing Company, 1994.

Banks, James A., Multiethnic education: Theory and practice, Oxford University Press: London, 1994.

Barton, Greg., "Memahami Abdurrabman Wabid", dalam kata pengantar Prisma Pemikiran Gus Dur, Yogyakarta: LKiS, 2010.

Catatan Akhir Tahun 2008 Gus Dur, Pluralisme di Indonesia Mengalami Krisis, http://wahidinstitute. diakses pada 14 Mei 2017

Dhakiri, M. Hanif., 41 Warisan Kebesaran Gus Dur, Yogyakarta: LKiS, 2010.

Efendi, Bactiar., "Mengembangkan Konsep Depriative Agama," dalam Jurnal Ulumul al Qur'an, Nomer 3 (1997), 44

Imanulhaq, Maman., Faqih, Fatwa dan Canda Gus Dur, Jakarta: Kompas, 2000. 
INCReS, Tim., Beyond The Symbols; Jejak Antropologis Pemikiran dan Gerakan Gus Dur, Bandung: PT Remaja Rosdakarya, 2000.

Iskandar, A. Muhaimin., Melanjutkean Pemikiran dan Perjuangan Gus Dur, Yogyakarta: LKiS, 2010.

Isnaini, Muhammad., Konsep Pendidikan Multikultural Dalam Merespon Tantangan Globalisasi, Bandung: Alpabeta, 2010.

M. Dawam Raharjo dalam Abdurrahman Wahid, Islam Indonesia Menatap Masa Depan, Jakarta: P3M, 1989.

Mahfud, Choirul., Pendidikan Multikultural, Yogyakarta: Pustaka Pelajar, 2006.

Masdar, Umaruddin., Membaca Pikiran Gus Dur dan Amin Rais Tentang Demokrasi, Yogyakarta: Pustaka Pelajar, 1999.

Misbahul Munir, Pemikiran KH. Abdurrabman Wabid Tentang Islam Berwawasan Multikultural Dan Implikasinya Terbadap Pendidikan Islam, Tesis, Surabaya: PAI Pasca Sarjana, UIN Sunan Ampel, 2014.

Misrawi, Zuhairi, "Pluralisme Pasca Gus Dur" dalam Sejuta Gelar Untuk Gus Dur, Jakarta: Pensil, 2010.

Musthofa, Pendidikan Multikultural dalam perspektif Gus Dur, Tesis, UIN Malang, 2015.

Nata, Abudin., Filsafat Pendidikan Islam, Jakarta: Logos, 1997.

Rifa'I, Muhammad., Gus Dur, KH. Abdurrahman Wabid Biografi Singkat 1940-2009, Jakarta: Ar-Ruzz Media, 2010.

Thoha, Zainal Arifin, Kenyelenehan Gus Dur: Gugatan Kaum Muda NU dan Tantangan Kebudayaan, Yogyakarta: Gama Media, 2001.

Tilaar, H.A.R, Kekuasaan dan Pendidikan Manajemen Pendidikan Nasional dalam Pusaran Kekuasaan, Bandung: Alpabeta, 2003.

Tilaar, H.A.R., Pendidikan, Kebudayaan, dan Masyarakat Madani Indonesia, Jakarta: Rineka Cipta, 2004.

Wahid, Abdurahman, Islam Indonesia Menatap Masa Depan, Jakarta: P3M, 1989.

Wahid, Abdurahman., Pergulatan Negara, Agama dan Kebudayaan, Depok: Desantara, 2001.

Wahid, Abdurrahman, dkk., Dialog: Kritik dan Identitas Agama, Yogyakarta: Pustaka Pelajar, 1993.

Wahid, Abdurrahman, Tuhan Tidak Perlu Dibela, Yogyakarta: LkiS, 1999.

Wahid, Abdurrahman., Islamku, Islam Kita, Islam Anda, Jakarta: The Wahid Institute, 2010.

Wahid, Abdurrahman., Prisma Pemikiran Gus Dur, Yogyakarta: LKiS, 2010. 
Wahid, Abdurrahman., Sistem Budaya Daerah Kita dan Modernisasi, dalam Abdurrabman Wahid, Islamku, Islam Anda Islam Kita, Cet. II, Jakarta: The Wahid Institute, 2006.

Zakiyuddin Baidhawy, The Problem of Multikulturalisme: Radicalism Mainstreaming Trought Religious Preaching in Surakarta. Journal of Indonesia Islam, Vol. 04, No. 02, 2010. 